\title{
Soil water content during and after plant growth influence nutrient availability and microbial biomass
}

\author{
Ran Xue ${ }^{1,2}$, Yuying Shen ${ }^{1}$, Petra Marschner ${ }^{2}$
}

${ }^{1}$ State Key Laboratory of Grassland Agro-ecosystems, College of Pastoral Agriculture Science and Technology, Lanzhou University, Lanzhou, 730020, China. ${ }^{2}$ School of Agriculture, Food and Wine, The University of Adelaide, South Australia, 5005, Australia

Corresponding author: petra.marschner@adelaide.edu.au

\begin{abstract}
Two experiments were conducted to study the effect of soil water content on soil respiration, microbial biomass and nutrient availability in planted and unplanted soil. In the first experiment, wheat was grown in pots for four weeks in soil that was kept dry between one and four weeks. In the second experiment, soil was maintained at $50 \%$ of water-holding capacity (WHC) for four weeks and either planted with wheat or left unplanted. After removal from the pots, soil was kept at 50\% WHC or quickly dried to 40, 30, 20 or 10\% of WHC. The soils were incubated four weeks during which soil respiration, microbial biomass and nutrient availability were measured. In the first experiment, shoot and root biomass and microbial biomass carbon were higher in constantly moist than constantly dry soil, but the reverse was true for available N. In the second experiment, cumulative respiration was two-fold higher in planted than unplanted soil and decreased with water content, with a smaller decrease in planted soil. Microbial biomass carbon on days 5 and 10 was higher at $10 \%$ than at $50 \%$ WHC in planted soil, but not affected by water content in unplanted soil. We conclude that soil microbes can maintain higher respiration at low water content despite low biomass because activity per unit biomass is high.
\end{abstract}

Keywords: Dry period, microbial biomass, planted, respiration, soil water content

\section{Introduction}

Water is considered as one of the most important factors influencing soil nutrient availability and microbial activity in terrestrial ecosystems (Clark et al., 2009). It is the medium of nutrient transport in soil, so although nutrient and water absorption are independent processes, they are inextricably linked to each other (Viets, 1972). Low water availability reduces decomposition and nutrient cycling rate
(Guntinas et al., 2013) because the thin water films around soil particles reduces diffusion of enzymes and nutrients and thus substrate supply for microbes (Papendick and Campell, 1981). To counteract the strongly negative water potential in dry soil, some microbes accumulate osmoregulatory compounds (e.g. polyols, sugar aldehydes and amino acids) (Harris, 1981), this physiological response avoids 
microbial dehydration and death. Plants are an important source of substrates for soil microbes through exudates and root debris (Merino et al., 2015; Berg and Smalla, 2009). Thus, low water availability may indirectly influence microbial activity by reducing substrate supply due to poor plant growth. When water content fluctuates during plant growth, plant growth may recover in moist periods sufficiently to compensate for poor growth during dry periods. But the effect of fluctuating water content during plant growth on soil nutrient availability and microbial biomass is poorly understood.

Differences in microbial biomass, composition and activity between planted and unplanted soil have been studied extensively. In a previous study, we imposed water stress during plant growth and found that the effect of low soil water content on microbes was exacerbated by low organic $\mathrm{C}$ input as a result of poor plant growth (Xue et al., 2016). However, the effect of intermittent dry on plant and microbial biomass is unclear. Further, it is not clear if the response of microbes to low water availability in planted soil after plant removal differs from that of microbes in unplanted soil.

The aims of this study were to determine (i) the effect of length and distribution of a dry period on plant growth, microbial biomass and nutrient availability (Experiment 1), and (ii) if the effect of low water availability on microbes and nutrient availability differs between planted and unplanted soil (Experiment 2 ). The hypotheses were that 1) plant growth and microbial biomass will decrease with length of the dry period with a greater effect if the dry period is in the early stages of plant growth, and 2) the effect of decreasing water content on soil respiration and microbial biomass will be smaller in planted soil than unplanted soil. The second hypothesis assumes that microbes with a greater supply of easily available $\mathrm{C}$ are more tolerant to stress.

\section{Materials and Methods}

\subsection{Soil}

The silt loam used in the experiments was collected on the Waite Campus of the University of Adelaide (Longitude $138^{\circ} 38^{\prime} 3.2^{\prime \prime} \mathrm{E}$, Latitude $34^{\circ} 58^{\prime} 0.2^{\prime \prime} \mathrm{S}$ ) at $0-10 \mathrm{~cm}$ depth. The site has Mediterranean climate with a hot, dry summer and cold, wet winter. The soil properties are: $22 \%$ sand, $60 \%$ silt, $18 \%$ clay, water holding capacity (WHC) $371 \mathrm{~g} \mathrm{~kg}^{-1}, \mathrm{pH}$ (1:5 soil water ratio) 5.6, EC (1:5) $0.1 \mathrm{dS} \mathrm{m}^{-1}$, total organic $\mathrm{C} 17 \mathrm{~g}$ $\mathrm{kg}^{-1}$, total organic $\mathrm{N} 1.5 \mathrm{~g} \mathrm{~kg}^{-1}$, bulk density $1.3 \mathrm{~g} \mathrm{~cm}^{-1}$, available P $10 \mathrm{mg} \mathrm{P} \mathrm{kg}^{-1}$ and available $\mathrm{N} 15 \mathrm{mg} \mathrm{N} \mathrm{kg}$ 1. Several samples were collected randomly and then pooled. The soil is a Rhodoxeralf according to US Soil Taxonomy. After stones and litter were removed, the soil was dried at $40{ }^{\circ} \mathrm{C}$, then sieved through a 2 $\mathrm{mm}$ sieve and thoroughly mixed before using it for the experiments.

\subsection{Experimental design}

Two experiments were conducted. For Experiment 1, soil water content was adjusted to either $50 \%(-0.078$ Mpa) WHC or $20 \%(-0.7 \mathrm{MPa}) \mathrm{WHC}$. The $50 \% \mathrm{WHC}$ was chosen because in previous studies with this soil, plants grew well at this water content. Then $400 \mathrm{~g}$ soil (dry weight equivalent) was filled in pots $(9.5 \times 8.5$ $\times 10 \mathrm{~cm})$ and planted with pre-germinated wheat seeds (Triticum aestivum L. cv. Krichauff, 15 seeds per pot). The experiment had nine treatments with four replicates per treatment that differed in watering regime (Figure 1). In CW, the soil was maintained throughout the four weeks at $50 \%$ WHC. In CD the soil was kept at $20 \%$ of WHC for four weeks. In the other treatments, the soil was at $20 \% \mathrm{WHC}$ for at least the first week. The treatment names refer to the number and order of weeks where the soil was watered to $50 \%$ 
WHC and weeks in which it was not watered (e.g. DWDD and DDWD were only watered in the second and third week, respectively). The pots were placed in a glasshouse with natural light. In the moist periods, water content was maintained at 50\% WHC and monitored three times a day by weight. During the dry periods, pots were left to dry until they reached $20 \%$ (within 2 days), after which this water content was maintained. After four weeks, plant roots and shoots were collected and dry weight measured. After carefully removing all visible roots, soils were kept at $4^{\circ} \mathrm{C}$ before the determination of available $\mathrm{N}$ and $\mathrm{P}$, water extractable organic $\mathrm{C}$ (WEOC) and microbial biomass $\mathrm{C}(\mathrm{MBC})$.

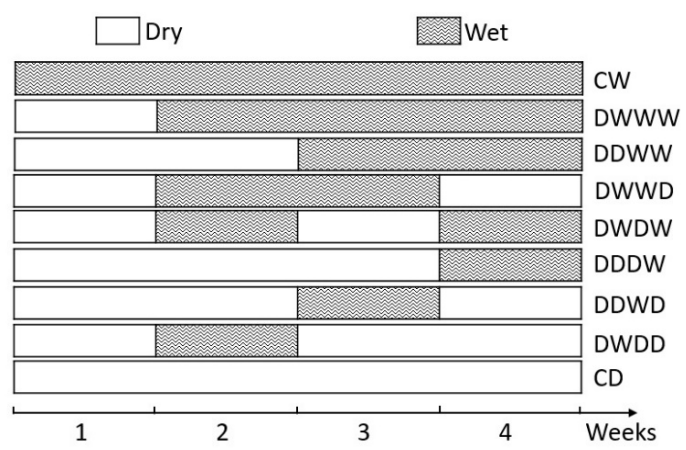

Figure 1. Schematic diagram of the watering treatments in Experiment 1.

The second experiment was carried out to assess the effect of low soil water content on microbial biomass, activity and nutrient availability in planted and unplanted soil. The soil was adjusted to $50 \% \mathrm{WHC}$. Then, soil (400 $\mathrm{g}$ dry weight equivalent) was filled into 16 pots. To obtain planted soil, eight of the pots were densely planted with pre-germinated wheat seeds ( 20 per pot). The high plant density was used to ensure high root density and therefore all soil in the planted pots was influenced by roots. The other eight pots remained unplanted. The pots were placed in a glasshouse with natural light and watered three times a day to maintain constant soil water content throughout plant growth. Any weeds germinating in the unplanted pots were removed. Four weeks after planting, when a dense plant cover was established in the planted pots, roots and shoots were removed.

The soil was dried in a fan-forced oven at $40{ }^{\circ} \mathrm{C}$ within $1-3 \mathrm{~h}$ to five water content contents $(10,20,30,40$ and
$50 \%$ of WHC, equivalent to $0.037,0.074,0.11,0.15$,

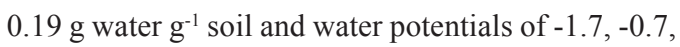
$-0.32,-0.16,-0.078 \mathrm{Mpa})$. These water contents correspond to volumetric water contents of 0.048, 0.097, $0.14,0.19,0.24 \mathrm{~g} \mathrm{~cm}^{-3}$. Then, $30 \mathrm{~g}$ soil (dry weight equivalent) of each water content treatment (each water content with 12 replicates, both planted and unplanted soils) was placed into PVC cores (height $5 \mathrm{~cm}$ and diameter $3.7 \mathrm{~cm}$ with a nylon mesh base). Soil bulk density was adjusted to $1.3 \mathrm{~g} \mathrm{~cm}^{-3}$ by packing the soil in the cores to the required height. Then the cores were transferred into glass jars and kept at $20-23{ }^{\circ} \mathrm{C}$ in the dark. The desired water content was maintained by weight every two days. Cores were destructively sampled on days 5, 10 and 25 with four replicates at each harvest for determination of WEOC, available $\mathrm{N}$ and $\mathrm{P}$, microbial biomass $\mathrm{C}$ (MBC), N (MBN). 


\subsection{Analyses}

Soil texture was determined using the hydrometer method (Bowman et al., 2002). WHC was measured using a sintered glass funnel (Haines, 1930). Soil was packed into rings and adjusted to field bulk density, placed in the sintered glass funnel which was connected to a $100 \mathrm{~mm}$ water column $\left(\psi_{\mathrm{m}}=10 \mathrm{kPa}\right)$ and thoroughly wetted. The soil was allowed to drain for $48 \mathrm{~h}$, dry weight of the soil was determined after oven drying at $105{ }^{\circ} \mathrm{C}$ till constant weight. Soil $\mathrm{pH}$ and EC were measured in a 1:5 (w/v) soil to reverse osmosis (RO) water ratio after $1 \mathrm{~h}$ end-over-end shaking. Soil total organic $\mathrm{C}$ was determined after Walkley and Black (1934). Soil total N was measured using the Kjeldahl method (McKenzie and Wallace, 1954).

Soil respiration was measured daily by quantifying the $\mathrm{CO}_{2}-\mathrm{C}$ concentration in the headspace of the jars using a Servomex 1450 infra-red analyzer (Servomex Group, Crowborough, UK) as described in (Setia et al., 2011). After each measurement, the jars were vented using a fan to refresh the headspace and then resealed for measurement on the following day. The $\mathrm{CO}_{2}$ evolved during a given interval was calculated as the difference in $\mathrm{CO}_{2}$ concentration between measured and ambient $\mathrm{CO}_{2}$ concentration. Linear regression based on injection of known amounts of $\mathrm{CO}_{2}$ into empty jars of similar size was used to define the relationship between $\mathrm{CO}_{2}$ concentration and detector reading.

Microbial biomass C (MBC) was determined by chloroform fumigation-extraction with $0.5 \mathrm{M} \mathrm{K}_{2} \mathrm{SO}_{4}$ at a 1:4 soil to extractant ratio (Vance et al., 1987). The organic $\mathrm{C}$ concentration in the filtered extract was measured by titration with $0.033 \mathrm{M}$ acidified $\left(\mathrm{NH}_{4}\right)_{2} \mathrm{Fe}\left(\mathrm{SO}_{4}\right)_{2} \cdot 6 \mathrm{H}_{2} \mathrm{O}$ after dichromate oxidation (Anderson and Ingram, 1993). The chloroform-labile C concentration is the difference between fumigated and non-fumigated soil which was multiplied by 2.64 to calculate MBC (Vance et al., 1987). For microbial biomass N (MBN), the am- monium concentration in the $\mathrm{K}_{2} \mathrm{SO}_{4}$ extract was determined (Willis et al., 1996; Moore et al., 2000). The difference between fumigated and non-fumigated soil was multiplied by 1.75 to calculate MBN (Moore et al., 2000). For determining soil available $\mathrm{N}$ (ammonium + nitrate), soil was extracted with $2 \mathrm{M} \mathrm{KCl}$ at a 1:5 soil to extractant ratio in a horizontal shaker at 80 rpm for one hour. Ammonium-N in the filtered extracts was measured as described for MBN after Willis et al. (1996). Nitrate-N was determined as described in Miranda et al. (2001). Available P was determined as described in Kouno et al. (1995). The P concentration in the extracts was determined colorimetrically according to Murphy and Riley (1962). Water extractable organic $\mathrm{C}$ (WEOC) was extracted at a 1:5 soil:water ratio. After $1 \mathrm{~h}$ end over end shaking, organic $\mathrm{C}$ was measured as described above for MBC.

\subsection{Statistical analysis}

Shoot and root biomass, MBC, WEOC, N and $\mathrm{P}$ in experiment 1 were analyzed by one-way analysis of variance. The second experiment was arranged in a complete randomized block design with 2 soil treatments (planted and unplanted soil) $\times 5$ water contents $\times$ 3 sampling times and 4 replicates for each sample time. Repeated measures ANOVA was performed to test the effect of treatment and soil water content over time using time as repeated measure. The interaction between sampling time and experimental treatments was significant. Therefore, data of cumulative respiration, available $\mathrm{N}, \mathrm{P}, \mathrm{WEOC}, \mathrm{MBC}$ and $\mathrm{MBN}$ per sampling time were subjected to two-way ANOVA (treatment $\times$ water content) for each sampling time separately. Average values were compared using post-hoc Tukey test. All analyses were carried out with Genstat (GenStat ${ }^{\circledR}$ for Windows, 18th edition, 2015; VSN International Ltd, Hemel Hempstead, UK). Only significant differences are mentioned in the text $(p<0.05)$. 


\section{Results}

\subsection{Experiment 1}

Shoot and root biomass were highest in the constantly wet $(\mathrm{CW})$ treatment and lowest in the constantly dry (CD) treatment (Figure $2 \mathrm{a}$ and $\mathrm{b}$ ). Shoot biomass was more sensitive to the constantly dry soil than root biomass. For example, shoot biomass was three times lower in CD than $\mathrm{CW}$ whereas root biomass was only $50 \%$ lower in $\mathrm{CD}$. Compared to $\mathrm{CW}$, shoot biomass was about $20 \%$ lower in the treatment with one dry week (DWWW). In treatments with two dry weeks, shoot biomass was highest in the treatment which was dry in the first and the last week (DWWD). Shoot biomass did not differ between treatments with two or three dry weeks, except in DDDW where it was lower than in DWWD and DWDW. Treatment differences were similar for root biomass, but with fewer significant differences than in shoot biomass. MBC had similar treatment differences as shoot and root biomass (Figure $2 \mathrm{c}$ ); it was about two-fold higher in $\mathrm{CW}$ than $\mathrm{CD}$ and among treatments with two dry weeks highest in DWWD. WEOC was about 30\% higher in $\mathrm{CW}$ than $\mathrm{CD}$ but the other treatments differed little in WEOC (Figure $2 \mathrm{~d}$ ).
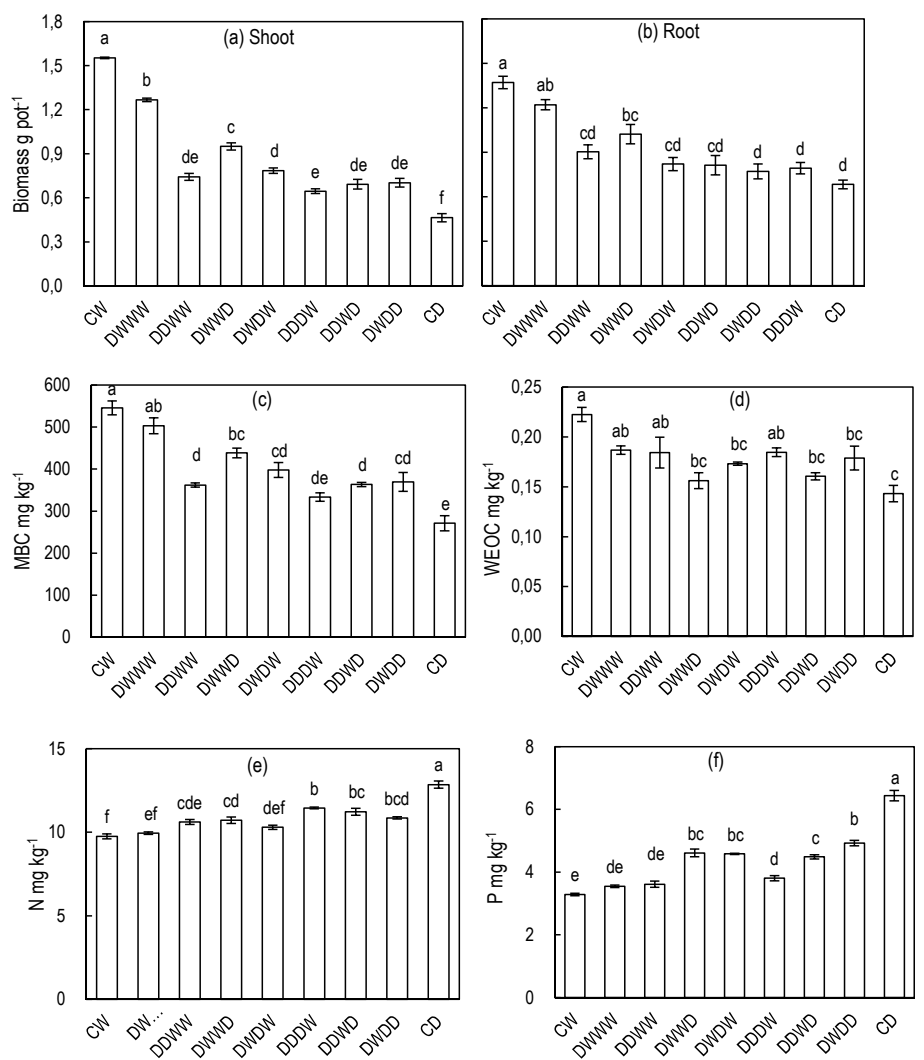

Figure 2. Shoot (a) and root biomass (b) of wheat, microbial biomass C (c), water extractable organic C (d), available $\mathrm{N}(\mathrm{e})$ and available $\mathrm{P}(\mathrm{f})$ concentration after four weeks in different watering treatments. Vertical lines at the top of the bars indicate standard error. Different letters indicate significant differences $(\mathrm{P}<0.05, \mathrm{n}=4)$. For treatment explanation see Figure 1. 
Available N and P (Figure 2 e and f) were lowest in $\mathrm{CW}$ and highest in $\mathrm{CD}$ with greater differences in available $\mathrm{P}$ (CW two-fold higher than $\mathrm{CD}$ ) than in available $\mathrm{N}$ (CW 30\% higher). Among treatments with varying water content, available $\mathrm{N}$ was lowest in the treatment with one week dry (DWWW) and highest with the first three weeks dry (DDDW).Available P was also lowest with one week dry (DWWW), but it was highest in the treatment with the second week wet (DWDD). In treatments with three dry weeks, available $\mathrm{P}$ increased in the following order: DDDW $<$ DDWD $<$ DWDD.

\subsection{Experiment 2}

\subsubsection{Cumulative respiration}

Cumulative respiration was about two-fold higher in planted than unplanted soil (Figure 3). It decreased with decreasing soil water content for both planted and unplanted soil. In planted soil, cumulative respiration decreased from 50 to $20 \% \mathrm{WHC}$. In unplanted soil, it decreased from 50 to $40 \%$ and from 20 to $10 \% \mathrm{WHC}$. The relative decrease in cumulative respiration compared to $50 \%$ WHC was smaller in planted than in unplanted soil. For example, at $30 \% \mathrm{WHC}$, cumulative respiration was $21 \%$ lower in planted soil, but $30 \%$ lower in unplanted soil.

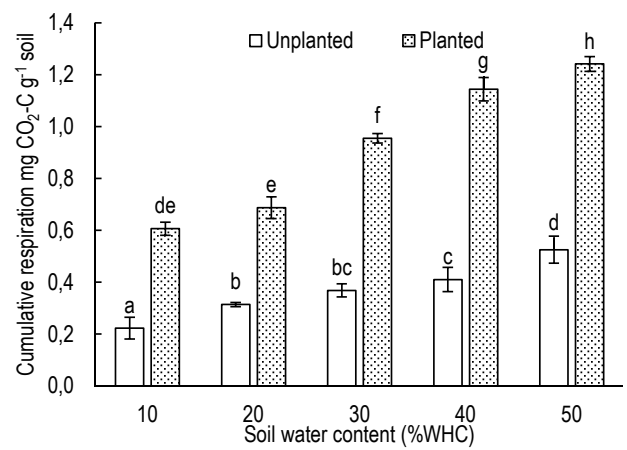

Figure 3. Cumulative respiration after 25 days in previously planted and unplanted soil with $10-50 \%$ of water holding capacity. Vertical lines at the top of the bars indicate standard error. Different letters indicate significant differences $(P<0.05, \mathrm{n}=4)$.

\subsubsection{Microbial biomass}

MBC was up to two-fold higher in planted soil than unplanted soil on day 5, later the differences became smaller or disappeared (Figure 4). Generally, MBC was higher on day 5 than days 10 and 25. The effect of soil water content on MBC differed between unplanted and planted soil and among sampling times. In planted soil, $\mathrm{MBC}$ was lower at 50\% than at $10 \%$ WHC. But the reverse was true for unplanted soil on days 5 and 25 (Figure $4 \mathrm{a}, \mathrm{c}$ ). The ratio of cumulative respiration to MBC on day 25 was about two-fold higher in planted than unplanted soil and two-fold lower at 10 compared to 50\% WHC (planted 2.1 and $5.1 \mathrm{mg} \mathrm{kg}^{-1}$; unplanted 1.1 and $2.1 \mathrm{mg} \mathrm{kg}^{-1}$ for 10 and $50 \% \mathrm{WHC}$, respectively). 


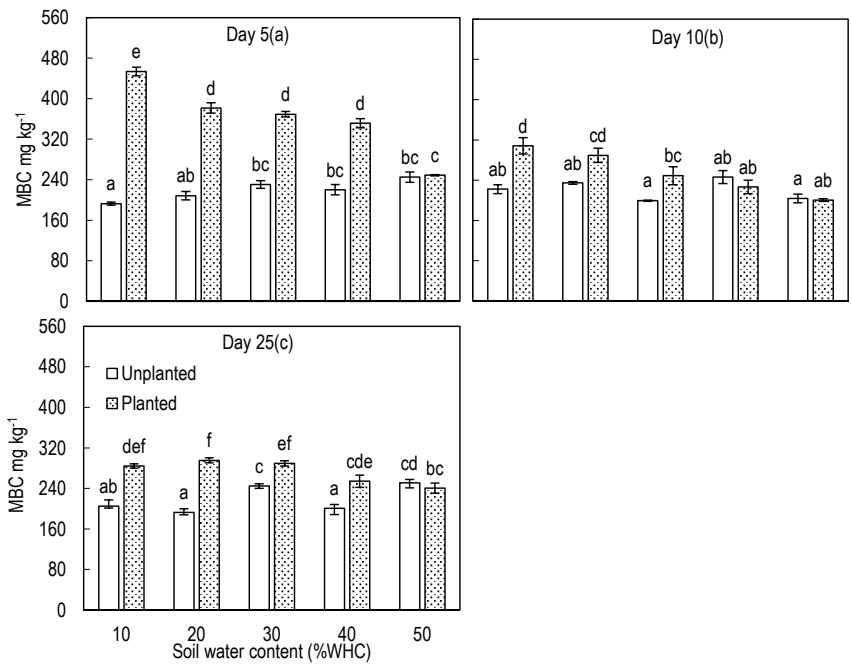

Figure 4. Microbial biomass $C$ concentrations on days 5 (a), 10 (b) and 25 (c) in previously planted and unplanted soil with $10-50 \%$ water holding capacity. Vertical lines at the top of the bars indicate standard error. Different letters on the same day indicate significant differences $(P<0.05, \mathrm{n}=4)$.

MBN was always about two-fold higher in planted than unplanted soil and changed little over time (Figure 5). In planted and unplanted soil, MBN was lowest at $10 \% \mathrm{WHC}$ at all sampling times and it was about two-fold higher at water contents $\geq 20 \% \mathrm{WHC}$ than at $10 \%$. In unplanted soil, MBN was lowest on day 25. In planted soil, it was also lowest on day 25 at $30-50 \%$ WHC, but not at 10 and $20 \%$ WHC.

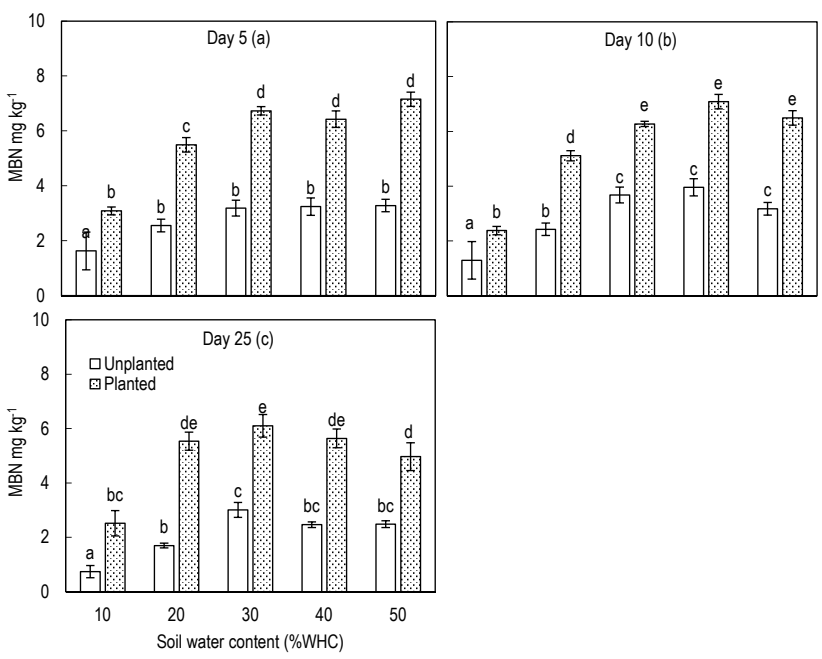

Figure 5. Microbial biomass $N$ concentrations on days 5 (a), 10 (b) and 25 (c) in previously planted and unplanted soil with $10-50 \%$ water holding capacity. Vertical lines at the top of the bars indicate standard error. Different letters on the same day indicate significant differences $(P<0.05, \mathrm{n}=4)$. 


\subsubsection{WEOC, available $\mathrm{N}$ and $\mathrm{P}$}

WEOC concentration was higher in planted than unplanted soil, with greater differences at higher water contents (Figure 6). At 50\% WHC, WEOC was at least two-fold higher in planted soil than unplanted soil, but at $10 \%$ it was only $20-30 \%$ higher. WEOC changed little over time. In planted soil, WEOC decreased with water content at all sampling times. It was $50-60 \%$ lower at $10 \%$ than at $50 \%$ WHC. Soil water content had little effect on WEOC in unplanted soil. On days 10 and 25, WEOC was lower at $10 \%$ than at $50 \% \mathrm{WHC}$, but the difference was quite small (about 20\% lower at 10\% WHC).
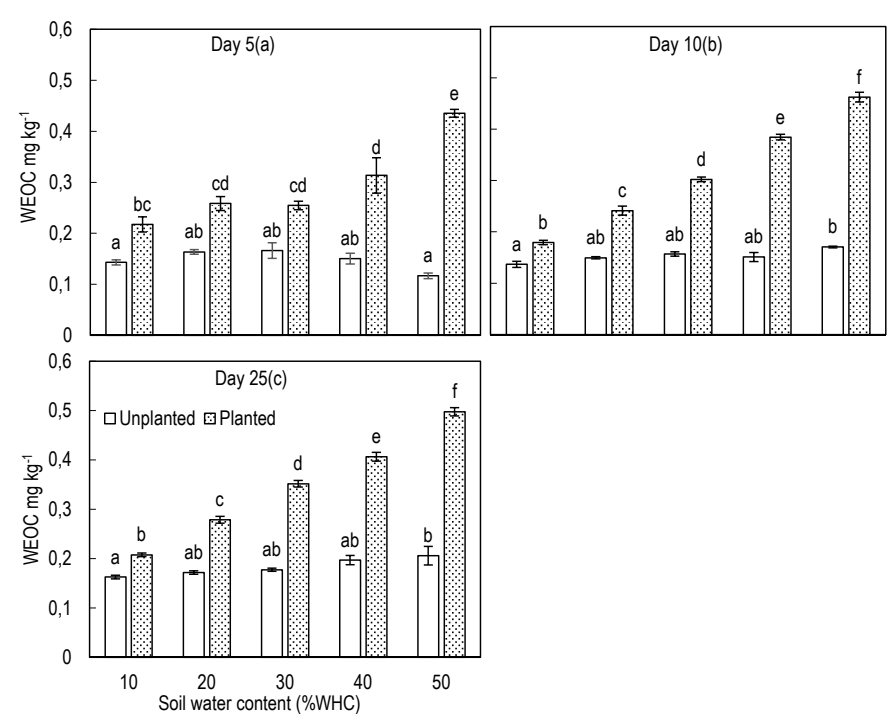

Figure 6. Water extractable organic $C$ concentrations on days 5 (a), 10 (b) and 25 (c) in previously planted and unplanted soil with $10-50 \%$ water holding capacity. Vertical lines at the top of the bars indicate standard error. Different letters on the same day indicate significant differences $(P<0.05, \mathrm{n}=4)$.

Available $\mathrm{N}$ was two-fold higher in unplanted than in planted soil (Table 1). It changed little over time. Soil water content had no clear effect on available
$\mathrm{N}$ in planted soil. In unplanted soil on days 5 and 10 , available $\mathrm{N}$ was $10-20 \%$ higher at $10 \% \mathrm{WHC}$ than at higher water contents. 
Table 1. Available N concentrations on day days 5, 10 and 25 in planted and unplanted soil at $10-50 \%$ of water holding capacity. Different letters on the same day indicate significant differences $(P<0.05, \mathrm{n}=4)$.

\begin{tabular}{lcrrr}
\hline \multirow{4}{*}{ Treatment } & \begin{tabular}{c} 
Soil water \\
content \\
\cline { 3 - 5 }
\end{tabular} & & \multicolumn{3}{c}{$\mathrm{N} \mathrm{mg} \mathrm{kg}^{-1}$} \\
\hline \multirow{5}{*}{ UWHC $)$} & & & \\
& 10 & $12.7 \mathrm{~d}$ & $11.4 \mathrm{e}$ & $10.1 \mathrm{c}$ \\
& 20 & $11.0 \mathrm{c}$ & $10.2 \mathrm{~d}$ & $9.4 \mathrm{c}$ \\
& 30 & $10.9 \mathrm{c}$ & $8.6 \mathrm{c}$ & $10.1 \mathrm{c}$ \\
& 40 & $10.8 \mathrm{c}$ & $8.4 \mathrm{c}$ & $9.4 \mathrm{c}$ \\
Planted & 50 & $10.9 \mathrm{c}$ & $9.0 \mathrm{c}$ & $10.1 \mathrm{c}$ \\
\hline & 10 & $4.2 \mathrm{~b}$ & $3.7 \mathrm{a}$ & $5.2 \mathrm{~b}$ \\
& 20 & $3.3 \mathrm{a}$ & $4.0 \mathrm{a}$ & $4.9 \mathrm{ab}$ \\
& 30 & $3.1 \mathrm{a}$ & $4.0 \mathrm{a}$ & $4.6 \mathrm{ab}$ \\
& 40 & $3.1 \mathrm{a}$ & $4.1 \mathrm{a}$ & $4.2 \mathrm{a}$ \\
& 50 & $3.9 \mathrm{~b}$ & $5.2 \mathrm{~b}$ & $5.3 \mathrm{~b}$ \\
\hline
\end{tabular}

Available P was two to three-fold lower in planted than in unplanted soil with greater differences on day 5 than later (Table 2).
In unplanted soil, available $\mathrm{P}$ decreased with time, while it was generally lowest on day 5 in planted soil.

Table 2. Available P concentrations on days 5, 10 and 25 in planted and unplanted soil at 10-50\% of water holding capacity. Different letters on the same day indicate significant differences $(P<0.05, \mathrm{n}=4)$.

\begin{tabular}{lcrrr}
\hline & & \multicolumn{3}{c}{$\mathrm{P} \mathrm{mg} \mathrm{kg}^{-1}$} \\
\cline { 3 - 5 } Treatment & $\begin{array}{c}\text { Soil water } \\
\text { content }\end{array}$ & Day 5 & Day 10 & Day 25 \\
& $(\%$ WHC $)$ & & & \\
\hline \multirow{4}{*}{ Unplanted } & 10 & $20.9 \mathrm{~d}$ & $19.8 \mathrm{e}$ & $15.2 \mathrm{~b}$ \\
& 20 & $19.3 \mathrm{c}$ & $18.0 \mathrm{~d}$ & $14.9 \mathrm{~b}$ \\
& 30 & $20.0 \mathrm{~cd}$ & $17.6 \mathrm{~d}$ & $15.1 \mathrm{~b}$ \\
& 40 & $19.8 \mathrm{~cd}$ & $17.8 \mathrm{~d}$ & $15.5 \mathrm{~b}$ \\
& 50 & $18.6 \mathrm{c}$ & $17.1 \mathrm{~d}$ & $15.5 \mathrm{~b}$ \\
\hline \multirow{4}{*}{ Planted } & 10 & $4.2 \mathrm{a}$ & $12.2 \mathrm{c}$ & $9.8 \mathrm{a}$ \\
& 20 & $5.2 \mathrm{a}$ & $10.6 \mathrm{~b}$ & $9.0 \mathrm{a}$ \\
& 30 & $9.6 \mathrm{~b}$ & $10.1 \mathrm{ab}$ & $9.2 \mathrm{a}$ \\
& 40 & $8.6 \mathrm{~b}$ & $9.6 \mathrm{a}$ & $9.5 \mathrm{a}$ \\
& 50 & $8.2 \mathrm{~b}$ & $9.3 \mathrm{a}$ & $8.9 \mathrm{a}$ \\
\hline
\end{tabular}




\section{Discussion}

This study showed that the effect of low soil water content on microbial biomass and nutrient availability depends on whether it is imposed during or after plant growth. Further, in the second experiment there were clear differences in the measured parameters between planted and unplanted soil in the effect of water content on respiration, microbial biomass and WEOC.

\subsection{Experiment 1}

The hypothesis (plant growth and microbial biomass will decrease with length of the dry period with a greater effect if the dry period is in the early stages of plant growth) cannot be unequivocally accepted or declined because the assessed plant and soil parameters differed little between the constantly moist treatment and that with one dry week followed by three wet weeks. But compared to $\mathrm{CW}$, two or more dry weeks decreased shoot and root biomass and MBC, whereas available $\mathrm{N}$ was increased. In agreement with previous studies (Matsui and Singh, 2003; Asch et al., 2005, Wang et al., 2014, Xue et al., 2016), the effect of low water content was greater for shoots than roots because plants invest relatively more carbon into roots than shoots when water availability is low to access the remaining water. The organic $\mathrm{C}$ input into the soil of the smaller plants in treatments with two or more dry weeks will be lower which explains the smaller MBC in these treatments. The higher $\mathrm{N}$ availability in treatments with two or more dry weeks compared to $\mathrm{CW}$ can be explained by lower nutrient uptake by the smaller plants. The lack of difference between treatments with different distribution of two or more dry weeks suggests that plant growth did not recover sufficiently in two moist weeks to compensate for the two dry weeks.

\subsection{Experiment 2}

As expected from previous studies, planted soil had higher concentrations of $\mathrm{WEOC}, \mathrm{MBC} / \mathrm{N}$ and also higher cumulative respiration than unplanted soil (Haynes and Francis, 1993; Liu et al., 2012). This can be explained by the greater substrate supply in planted soils via root exudates and root fragments that would be a source of nutrients for microbes (Wildung et al., 1975; Marschner, 2012) However, release of $\mathrm{C}$ and $\mathrm{N}$ by chloroform from root fragments could also lead to an overestimation of microbial biomass (Mueller et al., 1992). Differences in $\mathrm{MBC} / \mathrm{N}$ between planted and unplanted soil became smaller over time because $\mathrm{MBC} / \mathrm{N}$ decreased in planted soil, indicating depletion of relatively easily decomposable nutrients after separation from the roots. Available N and P as well as EC were lower in planted soil than unplanted soil as a result of nutrient uptake by the plants (Marschner, 2012). The higher $\mathrm{pH}$ suggests predominant nitrate uptake (Nye, 1981) which is corroborated by the low nitrate concentrations in planted soil (data not shown). The reduction in MBC at 20\% WHC compared to $50 \%$ in Experiment 2 was smaller than in Experiment 1 because, in Experiment 1, low water content affected both plant growth and soil microbes. In Experiment 2 on the other hand, plants grew in moist soil and different water contents were only imposed after removal of shoots and roots.

The hypothesis that the effect of decreasing water content on soil respiration and microbial biomass will be smaller in planted soil than unplanted soil cannot be unequivocally accepted or declined because the water content effect depended on the assessed parameters. In planted but not in unplanted soil, WEOC concentration decreased with water content. The plants were grown under well-watered conditions, therefore it can be assumed that the WEOC concentration was similar in all water treatments before drying. The ef- 
fect of water content on WEOC was apparent on day 5. Drying may have caused WEOC to bind to soil particles as water films became thinner. Later, WEOC concentration may also be influenced by microbial utilization and turnover as discussed below. Water content influenced WEOC only in planted soil where concentrations were up to two-fold greater than in unplanted soil.

Cumulative respiration decreased with water content in planted and unplanted soil which can be explained by thinning of water films around soil particles as soil dries which will reduce substrate diffusion to cells. At very low water content, water may also be drawn out of the cells (Ilstedt et al., 2000). As a result, the ratio of cumulative respiration to MBC on day 25 was twofold higher at $50 \%$ than at $10 \% \mathrm{WHC}$. The relative reduction of cumulative respiration with water content was slightly less in planted than unplanted soil (at $10 \%$ WHC compared to $50 \% \mathrm{WHC}$, cumulative respiration was 49 and $42 \%$ in planted and unplanted soil). This suggests that in planted soil, microbes are better able to remain active in dry soil, likely due to greater substrate availability. At higher substrate concentration in the soil solution, microbes may have access to substrates even when the water film is thin. This is corroborated by the two-fold higher ratio of cumulative respiration to $\mathrm{MBC}$ on day 25 at $10 \% \mathrm{WHC}$ in planted than unplanted soil.

Water content only had a consistent effect on MBC and $\mathrm{MBN}$ in planted soil where concentrations were up to two-fold higher than in unplanted soil. In planted soil, MBC on days 5 and 10 was lowest at $50 \%$ and highest at $10 \%$ WHC. This is likely due to differences in microbial turnover. At $50 \%$ WHC, microbes will rapidly decompose the root deposits left after the removal of the plants and part of the micro- bial biomass died after depletion of readily available substrates. The small biomass at 50\% WHC had high respiration rates as also indicated by the high ratio of cumulative respiration to MBC. The active biomass is likely to have high turnover rates which can explain the higher WEOC concentrations at this water content. At $10 \% \mathrm{WHC}$ on the other hand, microbial activity was low (two-fold lower ratio of cumulative respiration to $\mathrm{MBC}$ than at 50\% WHC) and thus root deposits only slowly decomposed. Therefore, more substrate remained after 5 and 10 days in dry soil which maintained a greater microbial biomass.

MBC decreased over time only in planted soil which does not seem to be due to organic $\mathrm{C}$ availability because WEOC concentrations remained unchanged throughout the experiment. However, WEOC composition may have changed. It is known that dissolved organic C (DOC) in soil can include simple as well as complex compounds (Amon and Benner, 1996). In this study, it is likely that at the start of the incubation, WEOC in planted soil was mainly easily decomposable compounds from root exudates and root cell lysates. Later as MBC decreased, a greater proportion of WEOC was microbial-derived which may be more complex and thus less readily decomposable than root exudates.

In contrast to $\mathrm{MBC}, \mathrm{MBN}$ in planted soil was lowest at $10 \%$ and highest at $50 \% \mathrm{WHC}$. Measured available $\mathrm{N}$ concentrations were not influenced by water content. However, $\mathrm{N}$ availability is determined at a 1:5 soil to $\mathrm{KCl}$ ratio, thus at very high water content. It is likely that at low water content, diffusion of $\mathrm{N}$ to cells and thus $\mathrm{N}$ uptake by microbes was reduced. The contrasting effect of water content on $\mathrm{MBC}$ and MBN in planted soil could be due to different levels of microbial activity. The MBC/MBN ratio was 
wider at $10 \%$ than at $50 \% \mathrm{WHC}(130$ and 35$)$. Growing microbes have a narrower $\mathrm{MBC} / \mathrm{MBN}$ ratio because they contain more $\mathrm{N}$-compounds (e.g. proteins, enzymes) than cells in stationary phase (Frankenberger and Dick, 1983). Thus, the narrow MBC/MBN ratio at $50 \% \mathrm{WHC}$ is in agreement with the high ratio of cumulative respiration to $\mathrm{MBC}$, both indicating highly active microbes. The less active microbial biomass at $10 \% \mathrm{WHC}$ had a wider $\mathrm{MBC} / \mathrm{MBN}$ ratio and a lower ratio of cumulative respiration to $\mathrm{MBC}$.

Soil water content had no clear effect on available $\mathrm{N}$ and $\mathrm{P}$ and any differences among water contents were small. This suggests that soil water content did not influence the ratio of mineralization to immobilization which also did not change over time.

\section{Conclusions}

The first experiment showed that the negative effect of low water content on microbial biomass $\mathrm{C}$ is exacerbated if the soil is dry during plant growth likely due to the lower organic $\mathrm{C}$ input into the soil by the smaller drought-stressed plants. Distribution of two or three dry weeks had little effect on the measured parameters suggesting that plants could not recover in one or two moist weeks.

From the second experiment we can conclude that microbes in planted soil can maintain higher respiration in dry soil despite low biomass because activity per unit biomass is high. Nevertheless, respiration was lower at low water content compared to optimal water content $(50 \% \mathrm{WHC})$ indicating that substrate availability was reduced. Further, MBC in previously planted soil decreased during the 25-day incubation which indicates that high activity may not be maintained much longer.

\section{Acknowledgements}

Ran Xue thanks the Chinese Scholarship Council for providing the scholarship.

\section{References}

Amon, R.M.W., Benner, R. 1996. Bacterial utilization of different size classes of dissolved organic matter. Limnol. Oceanogr. 41, 41-51.

Anderson, J., Ingram, J. 1993. Colorimetric determination of ammonium. Tropical Soil Biology and Fertility, A Handbook of Methods, second ed. CAB International, Wallingford, UK, pp: 73-74.

Asch, F., Dingkuhn, M., Sow, A., Audebert, A. 2005. Drought-induced changes in rooting patterns and assimilate partitioning between root and shoot in upland rice. Field Crops Res. 93, 223-236.

Berg, G., Smalla, K. 2009. Plant species and soil type cooperatively shape the structure and function of microbial communities in the rhizosphere. Fems Microbiol. Ecol. 68, 1-13.

Bowman, G., Hutka, J., McKenzie, N., Coughlan, K., Cresswell, H. 2002. Particle size analysis. Soil physical measurement and interpretation for land evaluation. CSIRO publishing, pp: 224-239.

Clark, J.S., Campbell, J.H., Grizzle, H., AcostaMartinez, V., Zak, J.C. 2009. Soil microbial community response to drought and precipitation variability in the Chihuahuan Desert. Microb. ecol. 57, 248-260.

Frankenberger, W., Dick, W. 1983. Relationships between enzyme activities and microbial growth and activity indices in soil. Soil Sci. Soc. Am. J. 47, 945-951.

Guntinas, M.E., Gil-Sotres, F., Leiros, M.C., TrasarCepeda, C. 2013. Sensitivity of soil respiration to moisture and temperature. J. Soil Sci. Plant Nutr. $13,445-461$. 
Haines, W.B. 1930. Studies in the physical properties of soil. V. The hysteresis effect in capillary properties, and the modes of moisture distribution associated therewith. J. Agr. Sci. 20, 97-116.

Harris, R. 1981. Effect of water potential on microbial growth and activity. Water potential relations in soil microbiology. Soil Science Society of America, Madison, pp: 23-95.

Haynes, R., Francis, G. 1993. Changes in microbial biomass $\mathrm{C}$, soil carbohydrate composition and aggregate stability induced by growth of selected crop and forage species under field conditions. J. Soil Sci. 44, 665-675.

Ilstedt, U., Nordgren, A., Malmer, A. 2000. Optimum soil water for soil respiration before and after amendment with glucose in humid tropical acrisols and a boreal mor layer. Soil Biol. Biochem. 32, 1591-1599.

Kouno, K., Tuchiya, Y., Ando, T. 1995. Measurement of soil microbial biomass phosphorus by an anion exchange membrane method. Soil Biol. Biochem. 27, 1353-1357.

Liu, D., Fang, S., Tian, Y., Dun, X. 2012. Variation in rhizosphere soil microbial index of tree species on seasonal flooding land: An in situ rhizobox approach. Appl. Soil Ecol. 59, 1-11.

Marschner, P. 2012. Mineral Nutrition of Higher Plants. Elsevier, pp: 360-368.

Matsui, T., Singh, B. 2003. Root characteristics in cowpea related to drought tolerance at the seedling stage. Exp. Agr. 39, 29-38.

McKenzie, H., Wallace, H.S. 1954. The Kjeldahl determination of nitrogen: a critical study of digestion conditions-temperature, catalyst, and oxidizing agent. Aust. J. Chem. 7, 55-70.

Merino, C., Nannipieri, P., Matus, F. 2015. Soil carbon controlled by plant, microorganism and mineralogy interactions. J. Soil Sci. Plant Nut. 15, 321-332.
Miranda, K.M., Espey, M.G., Wink, D.A. 2001. A rapid, simple spectrophotometric method for simultaneous detection of nitrate and nitrite. Nitric Oxide. 5, 62-71.

Moore, J., Klose, S., Tabatabai, M. 2000. Soil microbial biomass carbon and nitrogen as affected by cropping systems. Biol. Fert. Soils. $31,200-210$

Mueller, T., Joergensen, R., Meyer, B. 1992. Estimation of soil microbial biomass $\mathrm{C}$ in the presence of living roots by fumigationextraction. Soil Biol. Biochem. 24, 179-181.

Murphy, J., Riley, J.P. 1962. A modified single solution method for the determination of phosphate in natural waters. Anal. Chim. Acta. 27, 31-36.

Nye, P. 1981. Changes of $\mathrm{pH}$ across the rhizosphere induced by roots. Plant Soil. 61, 7-26.

Papendick, R., Camprell, G. 1981. Theory and measurement of water potential. Water potential relations in soil microbiology. Soil Science Society of America, Madison 1-22.

Setia, R., Marschner, P., Baldock, J., Chittleborough, D., Verma, V. 2011. Relationships between carbon dioxide emission and soil properties in salt-affected landscapes. Soil Biol. Biochem. 43, 667-674.

Vance, E., Brookes, P., Jenkinson, D. 1987. An extraction method for measuring soil microbial biomass C. Soil biol. Biochem. 19, 703-707.

Viets, F. 1972. Water deficits and nutrient availability. Water deficits and plant growth. Academic Press, New York, pp: 217-239.

Walkley, A., Black, I.A. 1934. An examination of the Degtjareff method for determining soil organic matter, and a proposed modification of the chromic acid titration method. Soil Sci. 37, 29-38. 
Wang, X., Mohamed, I., Xia, Y., Chen, F. 2014. Effects of water and potassium stresses on potassium utilization efficiency of two cotton genotypes. J. Soil Sci. Plant Nut. 14, 833-844.

Wildung, R., Garland, T., Buschbom, R. 1975. The interdependent effects of soil temperature and water content on soil respiration rate and plant root decomposition in arid grassland soils. Soil Biol. Biochem. 7, 373-378.
Willis, R.B., Montgomery, M.E., Allen, P.R. 1996. Improved method for manual, colorimetric determination of total Kjeldahl nitrogen using salicylate. J Agr Food Chem. 44, 1804-1807.

Xue, R., Shen, Y., Marschner, P. 2016. Low soil water content during plant growth influences soil respiration and microbial biomass after plant removal and rewetting. J. Soil Sci. Plant Nut. 16, 955-966. 